\title{
Effect of pre-treatment and drying methods on the content of minerals, B-group vitamins and tocopherols in kale (Brassica oleracea L. var. acephala) leaves
}

\author{
Anna $\operatorname{Korus}^{1}(\mathbb{D}$
}

Revised: 18 December 2020/Accepted: 29 January 2021/Published online: 10 February 2021

(C) The Author(s) 2021

\begin{abstract}
Dried vegetables are widely used in food production. Kale leaves, due to their high health-promoting properties, can be a valuable raw material for drying. The aim of the study was to evaluate the effect of blanching, drying methods (air-drying, freeze-drying), the time and temperature of storage on the content of ash, minerals, vitamins $\mathrm{B}_{1}, \mathrm{~B}_{2}$, and tocopherols in dried kale products. The dried products were evaluated directly after processing and after 12 months of storage at ambient temperature, $18-20{ }^{\circ} \mathrm{C}$ and cold temperature, $8-10{ }^{\circ} \mathrm{C}$. In $100 \mathrm{~g}$ dry matter from fresh raw material the dominant minerals were potassium $(2613 \mathrm{mg})$, calcium (1346 mg), phosphorus (432 mg), magnesium (129 mg). Kale leaves had $0.828 \mathrm{mg}$ vitamin $B_{1}, 1.533 \mathrm{mg}$ vitamin $B_{2}$ and $16.55 \mathrm{mg}$ total tocopherols per $100 \mathrm{~g}$ of dry matter. Blanching, applied prior to drying, significantly reduced the levels of minerals (3-38\%) and vitamins (8-45\%), except for calcium, zinc and manganese. This pre-treatment had, however, a beneficial effect, especially on vitamin retention during the storage of dried products. After 12 month storage, the losses of vitamin $B_{1}, B_{2}$ and total tocopherols in dried, previously blanched, raw materials ranged from 3 to $10 \%$, 1 to $4 \%$, and 1 to $16 \%$, respectively, depending on the type of sample. In the dried products obtained from unblanched raw material, the losses were larger and amounted to $10-17 \%, 8-16 \%$ and $4-17 \%$, respectively. Throughout drying and storage, the minerals examined were fairly
\end{abstract}

Anna Korus

rrkorusa@cyf-kr.edu.pl

1 Department of Plant Product Technology and Nutrition Hygiene, Faculty of Food Technology, University of Agriculture in Krakow, Balicka 122 Street, 30-149 Krakow, Poland stable. Dried kale is generally a good source of minerals and vitamins. However, blanching before drying is recommended. In addition, freeze-drying and storage in cold temperature allows for higher vitamin preservation in dried kale.

Keywords Kale $\cdot$ Blanching $\cdot$ Drying $\cdot$ Minerals $\cdot$ Bvitamins $\cdot$ Tocopherols

\section{Introduction}

Diet high in vegetables is widely recommended for its health-promoting properties. Vegetables are consumed raw or numerous processed products. Intake of vegetables has been associated with a reduced risk of chronic diseases and body weight management (Pem and Jeewon 2015). Most of the vegetables include high content of non-nutritive, nutritive, and bioactive compounds such as flavonoids, phenolic acids, anthocyanins, and as well as nutritive compounds such as sugars, essential oils, carotenoids, vitamins, and minerals (Arin and Arabaci 2019; Pennington and Fisher 2009; Zia-Ul-Haq et al. 2013). Studies indicate that human nutrition should be based on fruit and vegetables. These provide many valuable substances and significantly reduce the incidence of cardiovascular disease and diabetes, along with the associated mortality (Aune et al. 2017; Ülger et al. 2018). Therefore, we should eat fruit and vegetables as often as possible to improve overall health and reduce the risk of cardiovascular diseases and certain types of cancer. FAO/WHO (2015) suggests an intake of over $400 \mathrm{~g}$ of fruit and vegetables per day, which translates to about 5 portions per day. In addition, FAO/ WHO have been leading the global initiative 'Promotion of Fruit and Vegetables for Health' (PROFAV) to raise 
awareness and to boost fruit and vegetable production, supply and consumption, in order to improve people's health (FAO/WHO 2015). It should also be emphasised that nutritionists recommend eating as much green vegetables as possible as these are a source of many valuable components, for example, lutein, vitamin $\mathrm{K}_{1}$ (phylloquinone), folate, $\alpha$-tocopherol, $\beta$-carotene, and the flavonoid kaempferol.

Among green vegetables, kale (Brassica oleracea L. var. acephala) deserves special attention. It is rich in bioactive phytochemicals, such as phenolic compounds, glucosinolates and vitamins (Korus et al. 2014). Kale is an excellent source of vitamin $\mathrm{K}$ and a good source of omega3 fatty acids (in the form of alpha-linolenic acid) (Capurso et al. 2018). This species is also characterised by a high content of minerals (Armesto et al. 2019). Thavarajah et al. (2016) showed that a single $100 \mathrm{~g}$ serving of fresh kale can provide a significant percentage of the recommended daily intake of mineral micronutrients $(188-873 \mathrm{mg} \mathrm{K}$, 35-300 $\mathrm{mg} \mathrm{Ca}$ and $20-100 \mathrm{mg} \mathrm{Mg}$ ) identified by the United States Department of Agriculture (USDA 2015).

Kale is a seasonal vegetable and is susceptible to deterioration after harvesting due to its high water content. Therefore, the drying of kale ensures its preservation, easy storage, transport and availability over the year. Drying is one of the oldest methods of preserving plant materials. This method, due to the fact that removes almost all water from the product, allows the microbiological safety of the product to be ensured (Ghaboos et al. 2016; Saengrayap et al. 2015).

Dried foods are low water activity ranging from 0.03 to 0.7 (Chitrakar et al. 2019). A decreased water activity inhibits the growth of most bacteria, yeasts, and molds, which are unable to grow below 0.87, 0.88, and 0.80, respectively (Beuchat et al. 2013). Additionally, the blanching of vegetables before drying destroys the nonsporulating pathogens such as E. coli and Salmonella (International Commission on Microbiological Specifications for Foods 2005).

It should be emphasized that dried plant products are produced in many countries around the world, but there are increasing warnings about the presence of pathogens such as Salmonella. There are reported cases where many food borne illnesses were caused by the consumption of dried foods contaminated with Salmonella spp., Cronobacter spp., Staphylococcus spp. and E. coli. The bacterial population commonly isolated from dried vegetables include lactic acid bacteria, Enteroccoccus faecalis, Staphylococci, spores of Bacillus spp., yeasts and molds (Penicillium and Aspergillus spp.). With regard to pathogens in dried vegetables, the vegetative cells are rarely prezent (Chitrakar et al. 2019). Food safety affects food production and processing. Therefore, it is important the implementation of food safety programs in the food industry and improvements in hygiene education for people working with foods (El Sheikha 2016). The importance of the quality of the raw material for drying, production hygiene and appropriate packaging should be highlighted. The packaging of dehydrated vegetables must protect the product against moisture, air, dust, microorganisms, foreign odour, insects and rodents throughout storage. Heat and light also have a negative effect on the quality of the dried food (Sharangi and Datta 2015).

Convection drying by hot air (AD) is the most popular and traditional method of drying. However, while in contact with oxygen present in the air, the product is exposed to high temperatures for a long time. This, in turn, reduces the content of some valuable components, easily oxidised under such conditions (Ghaboos et al. 2016; Shende and Datta 2019). However, the application of lower temperatures, for example, during freeze-drying (FD), makes it is possible to produce high-quality dried products (Cheaib et al. 2018). Freeze drying, one of the more advanced drying methods, is a method which removes water from the frozen material mainly by sublimation. In this method, shrinkage is eliminated, and minimum losses of flavour, aroma and vitamins, along with near-perfect preservation results, are obtained (Antal et al. 2014). Compared to conventional drying, the key benefits of freeze-drying include the following: the retention of morphological, biochemical and immunological properties, high yield, long shelf life and reduced weight for storage and shipping (Ciurzyńska and Lenart 2011).

Dried products are being increasingly used in industries related to, for example, confectionery, bakery products and the production of functional foods. Drying technologies and the storage conditions of dried products should be adjusted to maintain the quality of dehydrated products. However, there is little in the literature on the effects of the pre-treatment of vegetables before drying and the storage time and temperature of dehydrated vegetables. Therefore, the aim of this study was to determine the effects of pretreatment (blanching), the method of drying (air or freezedrying), and 12 month storage at two temperatures on the content of ash, minerals ( $\mathrm{P}, \mathrm{K}, \mathrm{Ca}, \mathrm{Mg}, \mathrm{Na}, \mathrm{Fe}, \mathrm{Zn}, \mathrm{Mn}, \mathrm{Cu}$, $\mathrm{Cr}, \mathrm{Ni}, \mathrm{Pb}$ and $\mathrm{Cd})$, vitamins $\left(\mathrm{B}_{1}\right.$ and $\left.\mathrm{B}_{2}\right)$ and tocopherols $(\alpha-, \beta$ - and $\gamma$-tocopherol) in kale leaves (Brassica oleracea $\mathrm{L}$ var. acephala).

\section{Materials and methods}

\section{Materials}

The study material consisted of raw kale (Brassica oleracea L. var. acephala) leaves; leaves after blanching; 
leaves after air-drying (AD); and leaves after freeze-drying (FD). The dried products were evaluated directly after processing (0 months) and after 12 months of storage at ambient temperature, $18-20^{\circ} \mathrm{C}$ (A) and cold temperature, $8-10{ }^{\circ} \mathrm{C}(\mathrm{C})$.

The kale cultivar under investigation was Winterbor $F_{1}$, produced by the Dutch firm Bejo Zaden b.v. (Netherlands). This cultivar is classed among those most resistant to disease, yellowing of lower leaves and frost damage. Its leaves are dark green and strongly corrugated. The kale was grown from seedlings planted in an experimental field located in southern Poland. Seedlings were planted at spacings of $0.5 \times 0.5 \mathrm{~m}$ in late June. Mineral fertilization was applied according to the fertility of the soil and the nutritional requirements of the crop.

Kale was obtained from a single harvest during the last five days of September, 14 weeks after the seedlings were planted. The harvest consisted of cutting whole plants and removing unusable leaves. Leaves suitable for technological processing, i.e., not discoloured or damaged by pests or disease, then had their main veins removed. A random sample of approximately $5 \mathrm{~kg}$ was taken for analysis of chemical composition of the raw material. Part of the remaining material was then blanched before the whole was dried.

\section{Drying technology}

Non-blanched (NB) and blanched (B) raw leaves of kale were dried to the predetermined humidity level (below $5 \%$ ) by air or freeze-drying. The process of drying was preceded by the following preliminary treatments: removing the main vein, washing, cutting into $2 \mathrm{~cm}$ long pieces (Korus 2011).

Kale was blanched in a stainless steel vessel for $2.5 \mathrm{~min}$ at $96-98^{\circ} \mathrm{C}$, the proportion of water to the raw material being $5: 1$ by weight. After blanching, the material was cooled in cold water and left to drain on sieves for $30 \mathrm{~min}$ to remove excess water.

Air drying (AD) was carried out using Food dehydrator Profi Line (Hendi UK Ltd.), Model No: 229026 (1000 W). The weight of leaves on $1 \mathrm{~m}^{2}$ of sieves was $4.0 \mathrm{~kg}$. Cut kale leaves were dried at a temperature of $55^{\circ} \mathrm{C}, 5.0 \mathrm{~h}$.

Freeze-drying (FD) was preceded by freezing cut kale leaves for $80 \mathrm{~min}$ at $-40{ }^{\circ} \mathrm{C}$. Drying was carried out in a CHRIST Gamma 1-16 LCS lyophilizing cabinet. The weight of leaves on $1 \mathrm{~m}^{2}$ of trays was $4.0 \mathrm{~kg}$. The process of freeze-drying was begun at an initial temperature of $-25{ }^{\circ} \mathrm{C}$. The process was terminated after $30 \mathrm{~h}$ of drying, when the temperature of the dried material and that of the trays in the lyophilizing chamber reached $30{ }^{\circ} \mathrm{C}$.

After drying, the material was mixed and packed in airtight containers (glass twist-off jars $2.0 \mathrm{~L}$ in volume). The dried material was stored at two different temperatures until analysis:

- ambient temperature, $18-20{ }^{\circ} \mathrm{C}(\mathrm{A})$,

- cold temperature, $8-10^{\circ} \mathrm{C}(\mathrm{C})$.

\section{Chemical determination}

The ash content was determined by incinerating at $460{ }^{\circ} \mathrm{C}$ in an L 9/S 27 furnace oven (Nabertherm GmbH, Lilienthal, Germany) (Horwitz 2006). For the determination of individual mineral elements, the mineralisation of the material was carried out in a 3:1 mixture of nitric and perchloric acids. A $50 \mathrm{~g}$ portion of the material and $30 \mathrm{~mL}$ of the acid mixture were placed in $250 \mathrm{~mL}$ test tubes belonging to a Tecator Kjeltec Auto Plus II mineralisation set (FOSS, Hillerød, Denmark). The treated samples were left until the next day when complete mineralisation had occurred. The mineralised samples were diluted with ultrapure water to a volume of $100 \mathrm{~mL}$ and filtered into a dry flask. The content of the individual elements in the solutions was determined using a Jobin Yvon JY 238 Ultrace inductively coupled argon plasma emission spectrometer (Horiba, Kyoto, Japan). The level of $\mathrm{P}$ was determined by the method given in AOAC (Horwitz 2006).

The vitamin $\mathrm{B}_{1}$ and $\mathrm{B}_{2}$ content was determined according to HPLC methods (EN 14122:2014 (2014); EN 14152:2014 (2014)). Thiamine and riboflavin were detected simultaneously using a Merck liquid chromatograph with a fluorescence detector. Analysis was carried out on an Onyx Monolithic C18 column $(100 \times 4.6 \mathrm{~mm})$ with a pre-column. The fluorescence measurement was made at excitation and emission wavelengths of $360 \mathrm{~nm}$ and $503 \mathrm{~nm}$, respectively. Water (w) and acetonitrile (ac) $(t=0$ w/ac 88/12; $t=12$ w/ac $0 / 100)$ were used as the mobile phase with gradient elution at a flow rate of $1 \mathrm{~mL} / \mathrm{min}$.

The tocopherol content was determined according to a modification of the method of Katsanidis and Addis (1999) using normal phase HPLC. Tocopherols were extracted with hexane mixed with BHT. The analysis was carried out on a Merck liquid chromatograph with a fluorescence detector. The sample was injected onto a LUNA $\mathrm{NH}_{2}$ column $(250 \times 4.6 \mathrm{~mm})$ with a pre-column. Isocratic elution was carried out using a mixture of $n$-hexane and 2-propanol (95:5) at a flow rate of $2.5 \mathrm{~mL} / \mathrm{min}$. The wavelengths of excitation and emission were $290 \mathrm{~nm}$ and $330 \mathrm{~nm}$, respectively.

\section{Statistical analysis}

The obtained data were analyzed by one-factor analysis of variance, with three experimental replications. The Snedecor F and Student's $t$ tests, as well as the least significant 
difference (LSD), were calculated at probability levels of $p<0.05$. Statistica 12.0 (StatSoft Inc., Tulsa, USA) software was used.

\section{Results and discussion}

\section{Effect of blanching on the level of minerals and vitamins in kale leaves}

Dark green vegetables, including kale, are a good source of minerals (Dias 2019). Kale added to a cereal-based diet enhances the intake of essential minerals to combat micronutrient malnutrition (Migliozzi et al. 2015). The present study revealed that the average ash content in fresh kale leaves was $10.1 \mathrm{~g}$ per $100 \mathrm{~g}$ of dry matter (Table 1). The main ash components were potassium $(2613 \mathrm{mg} /$ $100 \mathrm{~g}$ ), calcium (1346 mg/100 g), phosphorus (432 mg/ $100 \mathrm{~g})$ and magnesium $(129 \mathrm{mg} / 100 \mathrm{~g})$. The remaining minerals were present in quantities below $100 \mathrm{mg} / 100 \mathrm{~g}$ dry weight (Table 1). It should, however, be noted that not all minerals are considered essential for the body to function as normal. Heavy metals pose a health risk due to their ability to accumulate in the body and long biological halflife. For example lead $(\mathrm{Pb})$, cadmium $(\mathrm{Cd})$ and arsenic (As) have a direct effect on the kidneys, and they are particularly nephrotoxic, even at 'normal' levels (Sabath and Robles-Osorio 2012). Fresh kale leaves contained $0.061 \mathrm{mg}$ of lead and $0.097 \mathrm{mg}$ of cadmium per $100 \mathrm{~g}$ dry matter (Table 1).

Table 1 Content of ash (g/100 g), macro- and microelements (mg/ $100 \mathrm{~g}$ ) in raw and blanched leaves of kale

\begin{tabular}{lccl}
\hline Item & Raw & \multicolumn{1}{l}{ Blanched } & LSD $p<0.05$ \\
\hline Ash & $10.1 \pm 0.18$ & $7.9 \pm 0.12$ & 2.15 \\
Potassium & $2613 \pm 161$ & $1612 \pm 122$ & 411.9 \\
Calcium & $1346 \pm 43$ & $1301 \pm 25$ & $\mathrm{~ns}$ \\
Phosphorus & $432 \pm 13$ & $358 \pm 17$ & 73.2 \\
Magnesium & $129 \pm 9$ & $112 \pm 11$ & 16.2 \\
Sodium & $51.6 \pm 5$ & $44.5 \pm 7$ & 6.22 \\
Iron & $15.0 \pm 2.2$ & $13.2 \pm 1.9$ & 1.95 \\
Zinc & $9.01 \pm 1.81$ & $8.57 \pm 1.71$ & $\mathrm{~ns}$ \\
Manganese & $6.46 \pm 1.11$ & $6.07 \pm 1.21$ & $\mathrm{~ns}$ \\
Copper & $7.13 \pm 1.62$ & $5.45 \pm 1.03$ & 1.58 \\
Chrome & $0.164 \pm 0.015$ & $0.156 \pm 0.011$ & 0.0072 \\
Nickel & $0.177 \pm 0.010$ & $0.164 \pm 0.009$ & 0.0124 \\
Lead & $0.061 \pm 0.005$ & $0.055 \pm 0.004$ & 0.0052 \\
Cadmium & $0.097 \pm 0.007$ & $0.086 \pm 0.006$ & 0.0109 \\
\hline
\end{tabular}

Values are presented as mean value $\pm \mathrm{SD}(n=3)$, in dry matter $n s$ not significant
The high vitamin content in kale is the factor that distinguishes this vegetable from other Brassica vegetables. The examined kale had $0.828 \mathrm{mg}$ vitamin $\mathrm{B}_{1}$ and $1.533 \mathrm{mg}$ vitamin $B_{2}$ in $100 \mathrm{~g}$ of dry matter. In turn, the total tocopherol content was $16.55 \mathrm{mg}$ per $100 \mathrm{~g}$ dry matter, including $\alpha$-tocopherol (80\%), $\gamma$-tocopherol (17\%) and $\beta$ tocopherol (3\%) (Table 2).

Thermal blanching is often a necessary operation preceding the main vegetable preservation process. The blanching treatment, by inactivating enzymes, including polyphenol oxidase (PPO) and peroxidase (POD), and removing air, has a beneficial effect on the quality of dried products (Garba et al. 2015; Xiao et al. 2017). In addition, blanching increases the drying rate by loosening vegetable tissue (Deng et al. 2019). This operation influences the loss of water-soluble compounds, for example, minerals and heat-sensitive vitamins. Santos et al. (2003) found that the decrease in the mineral content of vegetable leaves depends on the species and the time of the thermal treatment in water. The present study found that the blanching of kale leaves reduced the levels of ash on average by $21 \%$ and minerals by $3-38 \%$, with insignificant differences for calcium, zinc and magnesium (Table 1).

In turn, the losses of thiamine and riboflavin were, respectively, $9 \%$ and as much as $36 \%$. Lisiewska et al. (2003) recorded significant losses of both thiamine (45\%) and riboflavin (33\%) in the fresh weight of blanched fennel leaves; similar losses were observed by Słupski (2012) in common beans. The main reasons for the reduction observed in the contents of the examined vitamins are their water solubility and thermal destruction (Rickman et al. 2007). As for tocopherols, the largest losses due to blanching kale leaves were observed for $\gamma$-tocopherol (45\%) and $\beta$-tocopherol (21\%). Losses of $\alpha$-tocopherol were smaller, not exceeding $10 \%$ (Table 2). The nature of factors influencing the extent of changes resulting from heat treatment in water is complex. These factors include the ratio of vegetable weight to water during blanching and the contact surface of the raw material and medium (Lešková et al. 2006).

\section{Effect of drying on the level of minerals and vitamins in kale leaves}

Recently, there has been a growing consumer demand for convenient and ready-to-eat food. Dried fruits and vegetables are components of many convenience products, whose production and supply are currently increasing. Dried kale can be used, for example, for the production of powders considered as a good source of nutrients; it can also be a component of dietary supplements (Salehi and Aghajanzadeh 2020). Directly after air-drying, the products obtained had 9.84-9.86 $\mathrm{g}$ of ash, while the ash content in 
Table 2 Content of selected from B-group vitamins and tocopherols $(\mathrm{mg} / 100 \mathrm{~g})$ in raw, and blanched leaves of kale

\begin{tabular}{lccl}
\hline Item & Raw & Blanched & LSD $p<0.05$ \\
\hline Vitamin $B_{1}$ & $0.828 \pm 0.014$ & $0.767 \pm 0.005$ & 0.0227 \\
Vitamin $B_{2}$ & $1.533 \pm 0.013$ & $0.997 \pm 0.020$ & 0.0382 \\
$\alpha$-tocopherol & $13.30 \pm 0.16$ & $12.20 \pm 0.15$ & 0.831 \\
B-tocopherol & $0.506 \pm 0.070$ & $0.402 \pm 0.080$ & 0.0159 \\
$\gamma$-tocopherol & $2.741 \pm 0.012$ & $1.519 \pm 0.009$ & 0.0241 \\
Total tocopherols & $16.55 \pm 0.22$ & $14.12 \pm 0.31$ & 0.742 \\
\hline
\end{tabular}

Values are presented as mean value $\pm \operatorname{SD}(n=3)$, in dry matter freeze-dried products was 7.80-7.90 g per $100 \mathrm{~g}$ dry matter (Table 3). In the dried products from blanched leaves, the level of ash was lower, on average by $21 \%$, compared to those obtained from unblanched leaves, regardless of the drying method. After one year's storage, the ash level remained practically unchanged.

In the dried products, potassium (1575-2203 $\mathrm{mg} / 100 \mathrm{~g}$ ) and calcium (1138-1256 mg/100 g) were the minerals with the highest content (Table 3). The amounts of phosphorus $(352-402 \mathrm{mg})$ and magnesium $(108-121 \mathrm{mg})$ were also significant. Moreover, these products had $40.5-48.1 \mathrm{mg}$ sodium, $\quad 13.0-14.9 \mathrm{mg}$ iron, $8.52-10.51 \mathrm{mg}$ zinc, 5.85-6.02 mg manganese and 5.15-6.91 $\mathrm{mg}$ copper in $100 \mathrm{~g}$ (Tables 3, 4). Dried products from blanched leaves, compared to those obtained from unblanched ones, had lower levels of ash (20-21\%), macroelements (2-29\%) and microelements (2-25\%), since after blanching, the leaves had less of the aforementioned components. This is congruent with the opinion of other authors about losses of water-soluble components due to blanching (Huang et al.

Table 3 Content of ash $(\mathrm{g} / 100 \mathrm{~g})$ and macroelements $(\mathrm{mg} / 100 \mathrm{~g})$ in dried leaves of kale

\begin{tabular}{|c|c|c|c|c|c|c|}
\hline Type of dried product & Ash & Potassium & Calcium & Phosphorus & Magnesium & Sodium \\
\hline \multicolumn{7}{|l|}{0 months stored: } \\
\hline $\mathrm{AD}, \mathrm{NB}$ & $9.84 \pm 0.39$ & $1946 \pm 201$ & $1138 \pm 82$ & $399 \pm 9$ & $112 \pm 9$ & $41.3 \pm 1.1$ \\
\hline $\mathrm{FD}, \mathrm{NB}$ & $9.86 \pm 0.33$ & $2203 \pm 123$ & $1149 \pm 106$ & $402 \pm 16$ & $121 \pm 8$ & $48.1 \pm 1.8$ \\
\hline $\mathrm{AD}, \mathrm{B}$ & $7.80 \pm 0.20$ & $1575 \pm 102$ & $1220 \pm 68$ & $352 \pm 19$ & $109 \pm 8$ & $40.5 \pm 0.9$ \\
\hline $\mathrm{FD}, \mathrm{B}$ & $7.90 \pm 0.04$ & $1595 \pm 90$ & $1256 \pm 122$ & $356 \pm 17$ & $118 \pm 3$ & $43.6 \pm 1.6$ \\
\hline LSD $p<0.05$ & 0.423 & 202.3 & ns & 38.4 & 13.9 & 3.87 \\
\hline \multicolumn{7}{|l|}{ After 12 months stored: } \\
\hline $\mathrm{AD}, \mathrm{NBA}$ & $9.65 \pm 0.31$ & $1899 \pm 92$ & $1052 \pm 51$ & $368 \pm 11$ & $104 \pm 5$ & $36.9 \pm 2.0$ \\
\hline $\mathrm{AD}, \mathrm{NBC}$ & $9.76 \pm 0.33$ & $1907 \pm 87$ & $1108 \pm 90$ & $382 \pm 15$ & $111 \pm 6$ & $37.9 \pm 1.9$ \\
\hline FD, NBA & $9.77 \pm 0.38$ & $2045 \pm 71$ & $1088 \pm 17$ & $393 \pm 12$ & $110 \pm 8$ & $46.7 \pm 2.4$ \\
\hline $\mathrm{FD}, \mathrm{NBC}$ & $9.79 \pm 0.27$ & $2128 \pm 99$ & $1121 \pm 98$ & $397 \pm 17$ & $115 \pm 8$ & $47.0 \pm 2.2$ \\
\hline LSD $p<0.05$ & ns & 135.5 & ns & ns & ns & 3.29 \\
\hline $\mathrm{AD}, \mathrm{BA}$ & $7.76 \pm 0.36$ & $1512 \pm 23$ & $1200 \pm 96$ & $348 \pm 15$ & $102 \pm 4$ & $38.2 \pm 2.7$ \\
\hline $\mathrm{AD}, \mathrm{BC}$ & $7.76 \pm 0.17$ & $1524 \pm 48$ & $1215 \pm 73$ & $350 \pm 7$ & $103 \pm 6$ & $38.7 \pm 1.2$ \\
\hline $\mathrm{FD}, \mathrm{BA}$ & $7.79 \pm 0.32$ & $1585 \pm 93$ & $1205 \pm 85$ & $353 \pm 22$ & $103 \pm 3$ & $42.0 \pm 1.1$ \\
\hline $\mathrm{FD}, \mathrm{BC}$ & $7.79 \pm 0.42$ & $1590 \pm 90$ & $1225 \pm 84$ & $355 \pm 20$ & $105 \pm 5$ & $42.9 \pm 1.0$ \\
\hline LSD $p<0.05$ & ns & 65.6 & ns & ns & ns & 2.79 \\
\hline Total LSD $p<0.05$ & 0.430 & 151.2 & ns & 32.7 & 9.6 & 3.21 \\
\hline
\end{tabular}

Values are presented as mean value $\pm \operatorname{SD}(n=3)$, in dry matter

Type of product: $A D, N B$ air-dried from non-blanched kale; $F D, N B$ freeze-dried from non-blanched kale; $A D, B$ air-dried from blanched kale, $F D, B$ freeze-dried from blanched kale, $A D, N B A$ air-dried from non-blanched kale, stored in ambient temperature, $A D, N B C$ air-dried from nonblanched kale, stored in cold temperature, $F D, N B A$ freeze-dried from non-blanched kale, stored in ambient temperature, $F D, N B C$ freeze-dried from non-blanched kale, stored in cold temperature, $A D, B A$ air-dried from blanched kale, stored in ambient temperature, $A D, B C$ air-dried from blanched kale, stored in cold temperature, $F D, B A$ freeze-dried from blanched kale, stored in ambient temperature, $F D, B C$ freeze-dried from blanched kale, stored in cold temperature

$n s$ not significant 
Table 4 Content of microelements (mg/100 g) in dried leaves of kale

\begin{tabular}{|c|c|c|c|c|c|c|c|c|}
\hline $\begin{array}{l}\text { Type of dried } \\
\text { product }\end{array}$ & Iron & Zinc & Manganese & Copper & Chrome & Nickel & Lead & Cadmium \\
\hline \multicolumn{9}{|c|}{0 months stored: } \\
\hline $\mathrm{AD}, \mathrm{NB}$ & $14.9 \pm 0.82$ & $8.79 \pm 0.48$ & $5.26 \pm 0.41$ & $6.91 \pm 0.14$ & $0.160 \pm 0.006$ & $0.174 \pm 0.006$ & $0.059 \pm 0.004$ & $0.097 \pm 0.003$ \\
\hline FD, NB & $14.5 \pm 0.52$ & $8.89 \pm 0.28$ & $5.99 \pm 0.34$ & $6.69 \pm 0.26$ & $0.158 \pm 0.010$ & $0.161 \pm 0.018$ & $0.060 \pm 0.003$ & $0.086 \pm 0.005$ \\
\hline $\mathrm{AD}, \mathrm{B}$ & $13.0 \pm 0.15$ & $8.49 \pm 0.29$ & $5.02 \pm 0.08$ & $5.16 \pm 0.27$ & $0.152 \pm 0.010$ & $0.160 \pm 0.019$ & $0.053 \pm 0.002$ & $0.085 \pm 0.002$ \\
\hline $\mathrm{FD}, \mathrm{B}$ & $13.1 \pm 2.60$ & $8.52 \pm 0.43$ & $5.85 \pm 0.21$ & $5.15 \pm 0.19$ & $0.146 \pm 0.022$ & $0.156 \pm 0.010$ & $0.055 \pm 0.003$ & $0.083 \pm 0.003$ \\
\hline LSD $p<0.05$ & 0.8 & 0.585 & 0.444 & 0.341 & ns & 0.0221 & 0.0062 & 0.0055 \\
\hline \multicolumn{9}{|c|}{ After 12 months stored: } \\
\hline $\mathrm{AD}, \mathrm{NBA}$ & $14.5 \pm 0.93$ & $7.93 \pm 0.68$ & $4.58 \pm 0.33$ & $6.34 \pm 0.42$ & $0.141 \pm 0.008$ & $0.173 \pm 0.007$ & $0.046 \pm 0.003$ & $0.096 \pm 0.002$ \\
\hline $\mathrm{AD}, \mathrm{NBC}$ & $14.5 \pm 0.90$ & $7.72 \pm 0.34$ & $4.72 \pm 0.28$ & $6.57 \pm 0.38$ & $0.135 \pm 0.010$ & $0.172 \pm 0.006$ & $0.044 \pm 0.003$ & $0.093 \pm 0.005$ \\
\hline FD, NBA & $14.1 \pm 0.29$ & $7.88 \pm 0.16$ & $5.86 \pm 0.30$ & $6.60 \pm 0.23$ & $0.130 \pm 0.008$ & $0.161 \pm 0.020$ & $0.059 \pm 0.002$ & $0.087 \pm 0.005$ \\
\hline $\mathrm{FD}, \mathrm{NBC}$ & $14.2 \pm 0.38$ & $7.94 \pm 0.20$ & $5.86 \pm 0.33$ & $6.61 \pm 0.25$ & $0.131 \pm 0.011$ & $0.160 \pm 0.018$ & $0.059 \pm 0.004$ & $0.086 \pm 0.002$ \\
\hline LSD $p<0.05$ & ns & ns & 0.475 & ns & 0.0145 & 0.0124 & 0.0035 & ns \\
\hline $\mathrm{AD}, \mathrm{BA}$ & $12.5 \pm 0.93$ & $8.23 \pm 0.37$ & $5.00 \pm 0.08$ & $5.01 \pm 0.31$ & $0.155 \pm 0.007$ & $0.156 \pm 0.017$ & $0.060 \pm 0.002$ & $0.084 \pm 0.004$ \\
\hline $\mathrm{AD}, \mathrm{BC}$ & $12.7 \pm 0.90$ & $8.26 \pm 0.37$ & $4.98 \pm 0.16$ & $5.06 \pm 0.21$ & $0.153 \pm 0.009$ & $0.159 \pm 0.008$ & $0.059 \pm 0.004$ & $0.085 \pm 0.002$ \\
\hline $\mathrm{FD}, \mathrm{BA}$ & $12.8 \pm 0.29$ & $8.36 \pm 0.19$ & $5.37 \pm 0.39$ & $5.05 \pm 0.22$ & $0.150 \pm 0.010$ & $0.154 \pm 0.009$ & $0.055 \pm 0.002$ & $0.083 \pm 0.003$ \\
\hline $\mathrm{FD}, \mathrm{BC}$ & $12.9 \pm 0.38$ & $8.34 \pm 0.33$ & $5.43 \pm 0.44$ & $5.10 \pm 0.26$ & $0.147 \pm 0.007$ & $0.155 \pm 0.010$ & $0.054 \pm 0.003$ & $0.082 \pm 0.004$ \\
\hline LSD $p<0.05$ & ns & ns & ns & ns & 0.0129 & ns & ns & ns \\
\hline $\begin{array}{r}\text { Total LSD } \\
p<0.05\end{array}$ & 0.83 & 0.523 & 0.424 & 0.371 & 0.0161 & 0.0193 & 0.0047 & 0.0034 \\
\hline
\end{tabular}

Values are presented as mean value $\pm \mathrm{SD}(n=3)$, in dry matter

Abbreviations of type of dried product are the same as explained in footnote of Table 3

$n s$ - not significant

2016). Throughout storage, the level of macro- and micronutrients in the dried products did not change significantly. These components are regarded as fairly stable during storage, which agrees with our findings. It was also found that storage temperature had no significant effect on the level of macro- and microelements.

Of the micronutrients examined, zinc was found in the largest amount (8.52-8.89 $\mathrm{mg} / 100 \mathrm{~g})$, while with regard to the metals considered particularly dangerous to human health, it was nickel $(0.156-0.1774 \mathrm{mg} / 100 \mathrm{~g})$ and chromium $(0.146-0.160 \mathrm{mg} / 100 \mathrm{~g})$. Lead and cadmium were below $0.1 \mathrm{mg} / 100 \mathrm{~g}$ dry matter (Table 4). It should be highlighted that air-dried products, but only from unblanched raw material, had higher levels of lead and cadmium, compared to freeze-dried products, while the chromium and nickel contents were comparable in both products.

In contrast to minerals, the majority of the vitamins occurring in vegetables are sensitive to light, oxygen and especially to elevated temperatures (Santos et al. 2012). Drying lowered the vitamin content in kale leaves, and in this case the extent of the losses depended on the drying method. In freeze-dried products, the level of all the analysed vitamins was significantly higher (Table 5). During drying, vitamin losses were higher in the dried products obtained from the unblanched kale leaves, being as follows: $3-13 \%$ for vitamin $\mathrm{B}_{1}, 30-49 \%$ for vitamin $\mathrm{B}_{2}$ and $15-36 \%$ for total tocopherols. Immediately after drying, however, the products from the blanched raw material contained, in general, slightly less vitamins $\mathrm{B}_{1}$ and $\mathrm{B}_{2}$, compared to those from unblanched material, while their level of tocopherols was higher. It should be emphasised that after one year of storage, vitamins were better retained in the products obtained from blanched leaves. This result is consistent with the findings of Ramesh et al. (2001), who found that blanching led to lower vitamin losses in the samples blanched prior to drying than in unblanched leaves. In addition, vitamin losses were smaller in the dried kale kept at refrigeration temperature.

The degree of degradation will vary according to the vitamin and can also be affected by the processing and storage time to which the vegetable is submitted. Monitoring the vitamin content during processing and storage is of great importance to food technologists and consumers to assure the nutritious value of foods, and also for quality assurance purposes and regulatory compliance (Santos et al. 2012). In the process of drying, a high temperature is an important and characteristic feature, but it reduces the quality of the final product. Lower temperatures used, for 
Table 5 Content of selected from B-group vitamins and tocopherols $(\mathrm{mg} / 100 \mathrm{~g})$ in dried leaves of kale

\begin{tabular}{|c|c|c|c|c|c|c|}
\hline Type of dried product & Vitamin $\mathrm{B}_{1}$ & Vitamin $\mathrm{B}_{2}$ & $\alpha$-tocopherol & ß-tocopherol & $\gamma$-tocopherol & Total tocopherols \\
\hline \multicolumn{7}{|l|}{0 months stored: } \\
\hline $\mathrm{AD}, \mathrm{NB}$ & $0.722 \pm 0.029$ & $0.776 \pm 0.049$ & $10.05 \pm 0.41$ & $0.12 \pm 0.01$ & $0.42 \pm 0.03$ & $10.59 \pm 0.39$ \\
\hline $\mathrm{FD}, \mathrm{NB}$ & $0.803 \pm 0.035$ & $1.073 \pm 0.059$ & $11.41 \pm 0.34$ & $0.35 \pm 0.02$ & $2.35 \pm 0.15$ & $14.11 \pm 0.48$ \\
\hline $\mathrm{AD}, \mathrm{B}$ & $0.685 \pm 0.018$ & $0.734 \pm 0.032$ & $11.45 \pm 0.43$ & $0.20 \pm 0.02$ & $0.82 \pm 0.07$ & $12.47 \pm 0.50$ \\
\hline $\mathrm{FD}, \mathrm{B}$ & $0.757 \pm 0.050$ & $0.962 \pm 0.024$ & $12.07 \pm 0.25$ & $0.36 \pm 0.04$ & $1.30 \pm 0.09$ & $13.73 \pm 0.23$ \\
\hline LSD $p<0.05$ & 0.0542 & 0.0667 & 0.562 & 0.035 & 0.145 & 0.641 \\
\hline \multicolumn{7}{|l|}{ After 12 months stored: } \\
\hline $\mathrm{AD}, \mathrm{NBA}$ & $0.602 \pm 0.038$ & $0.685 \pm 0.034$ & $8.44 \pm 0.33$ & $0.04 \pm 0.01$ & $0.32 \pm 0.03$ & $8.78 \pm 0.36$ \\
\hline $\mathrm{AD}, \mathrm{NBC}$ & $0.632 \pm 0.038$ & $0.712 \pm 0.031$ & $8.87 \pm 0.29$ & $0.06 \pm 0.01$ & $0.38 \pm 0.02$ & $9.31 \pm 0.30$ \\
\hline $\mathrm{FD}, \mathrm{NBA}$ & $0.694 \pm 0.036$ & $0.902 \pm 0.030$ & $10.86 \pm 0.42$ & $0.28 \pm 0.02$ & $2.14 \pm 0.12$ & $13.28 \pm 0.53$ \\
\hline FD, NBC & $0.723 \pm 0.037$ & $0.944 \pm 0.033$ & $10.99 \pm 0.42$ & $0.30 \pm 0.02$ & $2.24 \pm 0.20$ & $13.53 \pm 0.54$ \\
\hline LSD $p<0.05$ & 0.0571 & 0.0490 & 0.567 & 0.021 & 0.180 & 0.682 \\
\hline $\mathrm{AD}, \mathrm{BA}$ & $0.624 \pm 0.038$ & $0.705 \pm 0.027$ & $9.86 \pm 0.32$ & $0.10 \pm 0.02$ & $0.56 \pm 0.03$ & $10.52 \pm 0.34$ \\
\hline $\mathrm{AD}, \mathrm{BC}$ & $0.653 \pm 0.037$ & $0.733 \pm 0.030$ & $10.31 \pm 0.42$ & $0.17 \pm 0.02$ & $0.72 \pm 0.03$ & $11.20 \pm 0.44$ \\
\hline $\mathrm{FD}, \mathrm{BA}$ & $0.699 \pm 0.032$ & $0.944 \pm 0.025$ & $11.74 \pm 0.57$ & $0.20 \pm 0.02$ & $1.07 \pm 0.06$ & $13.01 \pm 0.53$ \\
\hline $\mathrm{FD}, \mathrm{BC}$ & $0.746 \pm 0.038$ & $0.950 \pm 0.022$ & $12.07 \pm 0.25$ & $0.31 \pm 0.02$ & $1.19 \pm 0.11$ & $13.57 \pm 0.31$ \\
\hline LSD $p<0.05$ & 0.0560 & 0.0400 & 0.745 & 0.037 & 0.100 & 0.637 \\
\hline Total LSD $p<0.05$ & 0.0511 & 0.0524 & 0.537 & 0.030 & 0.134 & 0.599 \\
\hline
\end{tabular}

Values are presented as mean value $\pm \operatorname{SD}(n=3)$, in dry matter

Abbreviations of type of dried product are the same as explained in footnote of Table 3

example, in freeze-drying have a great potential for giving an improvement in the quality of dried products (Cheaib et al. 2018). Marić et al. (2020) noted that lyophilisation was less destructive to the original properties of the analysed root vegetables than convective drying, while Beaudry et al. (2004) pointed out the better quality of freezedried products; this technique, however, involves higher processing costs.

\section{Conclusion}

Drying plant materials with high water content extends their durability by reducing water activity and limiting enzymatic and microbiological processes. Dried products from kale can be components of other products, since they contain high amounts of minerals, B-group vitamins and tocopherols. When applied as food ingredients, they can give food new organoleptic features and increase its nutritional value. Each type of raw material, however, requires the use of specific conditions, the determination of which significantly affects the final quality of the obtained dried material. The application of improper drying parameters, especially temperature, can induce a number of undesirable changes, including losses in nutrients. However, particular attention should be given to the quality of the raw material, hygiene of production and storage conditions.

Our studies revealed that a high quality of dried products, especially vitamin retention, is determined by the pretreatment (blanching), the drying method and the storage conditions. As such products have a relatively long shelflife, blanching the raw material as a pre-treatment step produces a beneficial effect. Although the blanching of kale leaves led to losses in minerals and vitamins at this initial stage of processing, the losses observed in the products obtained from blanched leaves throughout their storage were smaller, especially with regard to vitamins $\mathrm{B}_{1}$ and $\mathrm{B}_{2}$, and the tocopherols, compared to the samples from unblanched leaves. In addition, lower losses of vitamins were observed in dried kale stored at a lower temperature.

Generally, dried products from kale can be components of other products, since they contain high amounts of minerals, B-group vitamins and tocopherols. When applied as food ingredients, they can give food new organoleptic features and increase its nutritional value.

With regard to dried vegetables, a food safety control policy and stringent quality control measures should be developed. In order to ensure the microbiological safety of dried food, it is important to take into account the quality of raw materials, processing and storage conditions. 
Acknowledgements This research was financed by the Ministry of Science and Higher Education of the Republic of Poland.

Funding Ministry of Science and Higher Education of the Republic of Poland.

\section{Compliance with ethical standards}

Conflict of interest Author declares no conflict of interest.

Open Access This article is licensed under a Creative Commons Attribution 4.0 International License, which permits use, sharing, adaptation, distribution and reproduction in any medium or format, as long as you give appropriate credit to the original author(s) and the source, provide a link to the Creative Commons licence, and indicate if changes were made. The images or other third party material in this article are included in the article's Creative Commons licence, unless indicated otherwise in a credit line to the material. If material is not included in the article's Creative Commons licence and your intended use is not permitted by statutory regulation or exceeds the permitted use, you will need to obtain permission directly from the copyright holder. To view a copy of this licence, visit http://creativecommons. org/licenses/by/4.0/.

\section{References}

Antal T, Kerekes B, Sikolya L, Tarek M (2014) Study on a two-stage vacuum freeze and hot-air drying method for apple cubes. In: Andrieu J, Perre P (eds) 19th International Drying Symposium. University C. Bernard Lyon Press, Lyon, France, pp 1-6

Arin L, Arabaci Ç (2019) The influence of exogenous capsaicin application on the germination, seedling growth, and yield of pepper. Turk J Agric For 43:500-507. https://doi.org/10.3906/ tar-1903-86

Armesto J, Gómez-Limia L, Carballo J, Martínez S (2019) Effects of different cooking methods on the antioxidant capacity and flavonoid, organic acid and mineral contents of Galega kale (Brassica oleracea var. acephala cv. Galega). Int J Food Sci Nutr 70:136-149. https://doi.org/10.1080/09637486.2018. 1482530

Aune D, Giovannucci E, Boffetta P, Fadnes LT, Keum N, Norat T, Greenwood DC, Riboli E, Vatten LJ, Tonstad S (2017) Fruit and vegetable intake and the risk of cardiovascular disease, total cancer and all-cause mortality-a systematic review and doseresponse meta-analysis of prospective studies. Int $\mathrm{J}$ Epidemiol 46:1029-1056. https://doi.org/10.1093/ije/dyw319

Beaudry C, Raghavan GSV, Ratti C, Rennie TJ (2004) Effect of four drying methods on the quality of osmotically dehydrated cranberries. Drying Technol 22:521-539. https://doi.org/10. 1081/DRT-120029999

Beuchat LR, Komitopoulou E, Beckers H, Betts RP, Bourdichon F, Fanning S, Joosten HM, ter Kuile BH (2013) Low-water activity foods: increased concern as vehicles of foodborne pathogens. J Food Prot 76:150-172. https://doi.org/10.4315/0362-028X. JFP-12-211

Capurso A, Crepaldi G, Capurso C (2018) Benefits of the Mediterranean diet in the elderly patient. Springer International Publishing, Cham

Cheaib D, El Darra N, Rajha HN, El-Ghazzawi I, Maroun RG, Louka $N$ (2018) Effect of the extraction process on the biological activity of lyophilized apricot extracts recovered from apricot pomace. Antioxidants (Basel) 7:11. https://doi.org/10.3390/ antiox7010011
Chitrakar B, Zhang M, Adhikari B (2019) Dehydrated foods: are they microbiologically safe? Crit Rev Food Sci Nutr 59:2734-2745. https://doi.org/10.1080/10408398.2018.1466265

Ciurzyńska A, Lenart A (2011) Freeze-drying-application in food processing and biotechnology - a review. Pol J Food Nutr Sci 61:165-171. https://doi.org/10.2478/v10222-011-0017-5

Deng L-Z, Mujumdar AS, Zhang Q, Yang X-H, Wang J, Zheng Z-A, Gao Z-J, Xiao H-W (2019) Chemical and physical pretreatments of fruits and vegetables: effects on drying characteristics and quality attributes - a comprehensive review. Crit Rev Food Sci Nutr 59:1408-1432. https://doi.org/10.1080/10408398.2017. 1409192

Dias JS (2019) Nutritional quality and effect on disease prevention of vegetables. Food Nutr Sci 10:369-402. https://doi.org/10.4236/ fns.2019.104029

El Sheikha A (2016) Food safety issues in Saudi Arabia. Nutr Food Technol 1. International commission on microbiological specifications for foods (2005) Microbial ecology of food commodities, 2nd ed. ICMSF, New York. https://doi.org/10.16966/24706086.103

EN 14122:2014 (2014) Foodstuffs. Determination of vitamin B1 by high performance liquid chromatography. ECS, Brussels, Belgium

EN 14152:2014 (2014) Foodstuffs. Determination of vitamin B2 by high performance liquid chromatography. ECS, Brussels, Belgium

FAO/WHO (2015) Promotion of fruit and vegetables for health. http://www.fao.org/3/a-i4935e.pdf. Accessed 30 April 2020

Garba U, Kaur S, Gurumayum S, Rasane P (2015) Effect of hot water blanching time and drying temperature on the thin layer drying kinetics of and anthocyanin degradation in black carrot (Daucus carota L.) shreds. Food Technol Biotechnol 53:324-330. https:// doi.org/10.17113/ftb.53.03.15.3830

Ghaboos SHH, Ardabili SMS, Kashaninejad M, Asadi G, Aalami M (2016) Combined infrared-vacuum drying of pumpkin slices. J Food Sci Technol 53:2380-2388. https://doi.org/10.1007/ s13197-016-2212-1

Horwitz W (ed) (2006) Official methods of analysis of AOAC International, 18th. ed. rev.1. AOAC International, Gaithersburg, MD, USA

Huang Y, Xiao D, Burton-Freeman BM, Edirisinghe I (2016) Chemical changes of bioactive phytochemicals during thermal processing. In: Smithers GW (ed) Reference module in food science. Elsevier, Amsterdam

International Commission on Microbiological Specifications for Foods (2005) Microbial ecology of food commodities, 2nd edn. ICMSF, New York

Katsanidis E, Addis PB (1999) Novel HPLC analysis of tocopherols, tocotrienols, and cholesterol in tissue. Free Radical Biol Med 27:1137-1140. https://doi.org/10.1016/s0891-5849(99)00205-1

Korus A (2011) Effect of preliminary processing, method of drying and storage temperature on the level of antioxidants in kale (Brassica oleracea L. var. acephala) leaves. LWT-Food Sci Technol 44:1711-1716. https://doi.org/10.1016/j.lwt.2011.03. 014

Korus A, Słupski J, Gębczyński P, Banaś A (2014) Effect of preliminary processing and method of preservation on the content of glucosinolates in kale (Brassica oleracea L. var. acephala) leaves. LWT-Food Sci Technol 59:1003-1008. https://doi.org/10.1016/j.lwt.2014.06.030

Lešková E, Kubíková J, Kováčiková E, Košická M, Porubská J, Holčíková K (2006) Vitamin losses: retention during heat treatment and continual changes expressed by mathematical models. J Food Compos Anal 19:252-276. https://doi.org/10. 1016/j.jfca.2005.04.014 
Lisiewska Z, Słupski J, Zuchowicz E (2003) Effect of temperature and storage period on the preservation of vitamin $\mathrm{C}$, thiamine and riboflavin in frozen dill (Anethum graveolens L.). http:// www.ejpau.media.pl/volume6/issue2/food/art-07.html. Accessed 30 April 2020

Marić L, Malešić E, Jurinjak Tušek A, Benković M, Valinger D, Jurina T, Gajdoš Kljusurić J (2020) Effects of drying on physical and chemical properties of root vegetables: artificial neural network modelling. Food Bioprod Process 119:148-160. https:// doi.org/10.1016/j.fbp.2019.11.002

Migliozzi M, Thavarajah D, Thavarajah P, Smith P (2015) Lentil and kale: complementary nutrient-rich whole food sources to combat micronutrient and calorie malnutrition. Nutrients 7:9285-9298. https://doi.org/10.3390/nu7115471

Pem D, Jeewon R (2015) Fruit and vegetable intake: benefits and progress of nutrition education interventions-narrative review article. Iran J Public Health 44:1309-1321

Pennington JA, Fisher RA (2009) Classification of fruits and vegetables. J Food Compos Anal 22:S23-S31. https://doi.org/ 10.1016/j.jfca.2008.11.012

Ramesh MN, Wolf W, Tevini D, Jung G (2001) Influence of processing parameters on the drying of spice paprika. J Food Eng 49:63-72. https://doi.org/10.1016/S0260-8774(00)00185-0

Rickman JC, Barrett DM, Bruhn CM (2007) Nutritional comparison of fresh, frozen and canned fruits and vegetables. Part 1. Vitamins C and B and phenolic compounds. J Sci Food Agric 87:930-944. https://doi.org/10.1002/jsfa.2825

Sabath E, Robles-Osorio ML (2012) Renal health and the environment: heavy metal nephrotoxicity. Nefrologia 32:279-286. https://doi.org/10.3265/Nefrologia.pre2012.Jan.10928

Saengrayap R, Tansakul A, Mittal GS (2015) Effect of far-infrared radiation assisted microwave-vacuum drying on drying characteristics and quality of red chilli. J Food Sci Technol 52:2610-2621. https://doi.org/10.1007/s13197-014-1352-4

Salehi F, Aghajanzadeh S (2020) Effect of dried fruits and vegetables powder on cakes quality: a review. Trends Food Sci Technol 95:162-172. https://doi.org/10.1016/j.tifs.2019.11.011

Santos MATd, Abreu CMPd, Carvalho VDd (2003) Efeito de diferentes tempos de cozimento nos teores de minerais em folhas de brócolis, couve-flor e couve (Brassica oleracea L.).
Ciênc agrotec 27:597-604. https://doi.org/10.1590/S141370542003000300015

Santos J, Mendiola JA, Oliveira MBPP, Ibáñez E, Herrero M (2012) Sequential determination of fat- and water-soluble vitamins in green leafy vegetables during storage. J Chromatogr A 1261:179-188. https://doi.org/10.1016/j.chroma.2012.04.067

Sharangi AB, Datta S (2015) Value addition of horticultural crops: recent trends and future directions. Springer India, New Delhi. https://doi.org/10.1016/j.jfca.2008.11.012

Shende D, Datta AK (2019) Refractance window drying of fruits and vegetables: a review. J Sci Food Agric 99:1449-1456. https:// doi.org/10.1002/jsfa. 9356

Słupski J (2012) Effect of freezing and canning on the thiamine and riboflavin content in immature seeds of five cultivars of common bean (Phaseolus vulgaris L.). Int J Refrig 35:890-896. https:// doi.org/10.1016/j.ijrefrig.2011.12.001

Thavarajah D, Thavarajah P, Abare A, Basnagala S, Lacher C, Smith P, Combs GF (2016) Mineral micronutrient and prebiotic carbohydrate profiles of USA-grown kale (Brassica oleracea L. var. acephala). J Food Compos Anal 52:9-15. https://doi.org/ 10.1016/j.jfca.2016.07.003

Ülger TG, Songur AN, Çırak O, Çakıroğlu FP (2018) Role of vegetables in human nutrition and disease prevention. In: Asaduzzaman M, Asao T (eds) Vegetables-Importance of quality vegetables to human health. InTech, London, UK, pp 7-32

USDA (2015) Dietary Guidelines for Americans. www.dietaryguide lines.gov. Accessed 30 April 2020

Xiao H-W, Pan Z, Deng L-Z, El-Mashad HM, Yang X-H, Mujumdar AS, Gao Z-J, Zhang Q (2017) Recent developments and trends in thermal blanching-A comprehensive review. Inf Process Agric 4:101-127. https://doi.org/10.1016/j.inpa.2017.02.001

Zia-Ul-Haq M, Ahmad S, Qayum M, Ercisli S (2013) Compositional studies and antioxidant potential of Albizia lebbeck (L.) Benth Pods and seeds. Turk J Biol 37:25-32

Publisher's Note Springer Nature remains neutral with regard to jurisdictional claims in published maps and institutional affiliations. 